\title{
PHYTOSOCIOLOGICAL STUDY IN ICE-FREE AREAS OF ARCTOWSKI REGION, ADMIRALTY BAY, KING GEORGE ISLAND, ANTARCTICA
}

\author{
Gillian Nunes Pinto*, Margeli Pereira de Albuquerque, \\ Filipe de Carvalho Victoria \& Antônio Batista Pereira
}

Universidade Federal do Pampa - UNIPAMPA, Campus São Gabriel, Av. Antônio Trilha, 1847, CEP 97300-000, São Gabriel, RS, Brasil *e-mail:gillianpinto@yahoo.com.br

\begin{abstract}
This study was undertaken in ice-free areas adjacent to the Polish Antarctic Station Henryk Arctowski, during the austral summer 2013/2014. Phytossociological surveys were made in vegetation patches in the region, where a total of $33220 \times 20 \mathrm{~cm}$ quadrats were launched in $10 \mathrm{~m}$ transects. The five most frequent species in the samples were selected and their data are presented in this work. To check the most frequent species in the samples the index of ecological significance (IES) was used. The most important species were Deschampsia antarctica Desv. and Colobanthus quitensis (Kunth) Bartl the only one angiosperms occurring in Antarctica. Sanionia uncinata (Hedw.) Loeske Politrichastrum alpinum (Hedw.) G.L.Sm. and Syntrichia magellanica (Mont.) R.H. Zander. were the most representative moss species. The data of ecological significance of these species were compared to previous results in order to evaluate the changes in the vegetation in 10 year long-time monitoring.
\end{abstract}

Keywords: Phytosociology, Arctowski, Index of Ecological Significance

\section{Introduction}

The King George Island is located in the archipelago of the South Shetland Islands $\left(61^{\circ} 50^{\prime}-62^{\circ} 15^{\prime}\right.$ 'S and $57^{\circ} 30^{\prime}$ $\left.59^{\circ} 00^{\prime} \mathrm{W}\right)$. Admiralty Bay is located in its southeastern side, a region with a protected microclimate, very different compared to other parts of the island, especially in relation to the winds (Pereira \& Putzke 1994). The special geographical position and the uniqueness of the ecosystem in the Antarctic islands make the studies in these areas as vital for understanding the worldwide environmental changes. The plant communities in Antarctica are highly sensitive and dependent on several environmental factors; such studies of Antarctic species are indispensable. The plants in Antarctica have great potential as global change biomarkers. According to Lewis-Smith (2001), since 1940 there is evidence of global warming influence on plant development in the Maritime Antarctic, especially regarding the land cover changes. The index of ecological significance the index of ecological importance was applied (Lara \& Mazimpaka, 1998), which combines the parameters of abundance (coverage and frequency). (IES), was used as an important tool for studying the fluctuations of plant communities in Antarctica (Victoria \& Pereira, 2007). The aim of this study has been to evaluate the vegetation cover changes adjoining to Henryk Arctowski station.

\section{Materials and Methods}

This present work was undertaken in the austral summer 2013/2014 during the activities of Brazilian Antarctic Program expedition XXXI, the index of ecological significance (IES). It is a study in Phytosociological vegetation patches in the Arctowski region, Admiralty Bay, King George Island, Antarctica. A total of $33220 \times 20$ quadrats in the plant communities found adjoining the Polish Antarctic Station Henryk Arctowski. Transects were launched in plant patches, measuring $10 \mathrm{~m}$ each, where the vegetation cover and diversity were evaluated, according to Braun-Blanquet (1932) with adaptations (Kanda, 1986) 
(Figure 1b). To evaluate the composition of mosses and angiosperms in the area were the IES (Lara \& Mazimpaka, 1998) was estimated following.

\section{Results}

From the data obtained from the phytosociological sampling, the vegetation was separated between mosses and angiosperms, in that five species were the most found in the quadrats sampled (Table 1). Dechampsia antarctica Desv. and Colobanthus quitensis (Kunth) Bartl, are the most frequent species in this area. Among mosses, Sanionia uncinata (Hedw.) Loeske, Polytrichastrum alpinum (Hedw.) G.L.Sm.e Syntrichia magellanica (Mont.) R.H. Zander are the most commonly found moss species. The index of ecological significance (IES) (Table-1) ranges from 0 to 600 , but in practice the values above 400 are very rare, but if it represents a taxon with domain almost absolute sampling (Lara \& Mazinpaka, 1998). However, global values above 50 show an ecological significance in Antarctica.

The Deschampsia antarctica, Sanionia uncinata and Politrichastrum alpinum, was identified with IES $>50$ and are considered as the most important species in the area. The grass species proved to be a high dominant species in this region (IES $=358.31$ ), exceeding the other species in the samples.

This data was compared with phytosociological study conducted by Victoria et al. (2009) (Figure 1a), in the austral summer of 2003/2004. There have been some significant changes a priori in species coverage, such Polytrichastrum

Table 1. Four samples of the most representative species and their rates of ecological value and $I E S=Q=N^{\circ}$ samples numbers were present during the two austral summers 2003/2004 and 2013/2014.

\begin{tabular}{ccccc} 
Species & $\mathbf{N}^{\circ} \mathbf{Q} \mathbf{2 0 0 3 / 2 0 0 4}$ & $\mathbf{N}^{\circ} \mathbf{Q} \mathbf{2 0 1 3 / 2 0 1 4}$ & IES 2003/2004 & IES 2013/2014 \\
Deschampsia antarctica & 190 & 250 & 245.8 & 358.31 \\
Sanionia uncinata & 177 & 162 & 215.20 & 269.76 \\
Politrichastrum alpinum & 146 & 105 & 153.54 & 81.11 \\
Syntrichia magellanica & 21 & 49 & 22.96 & 20.96 \\
\hline
\end{tabular}

(a)
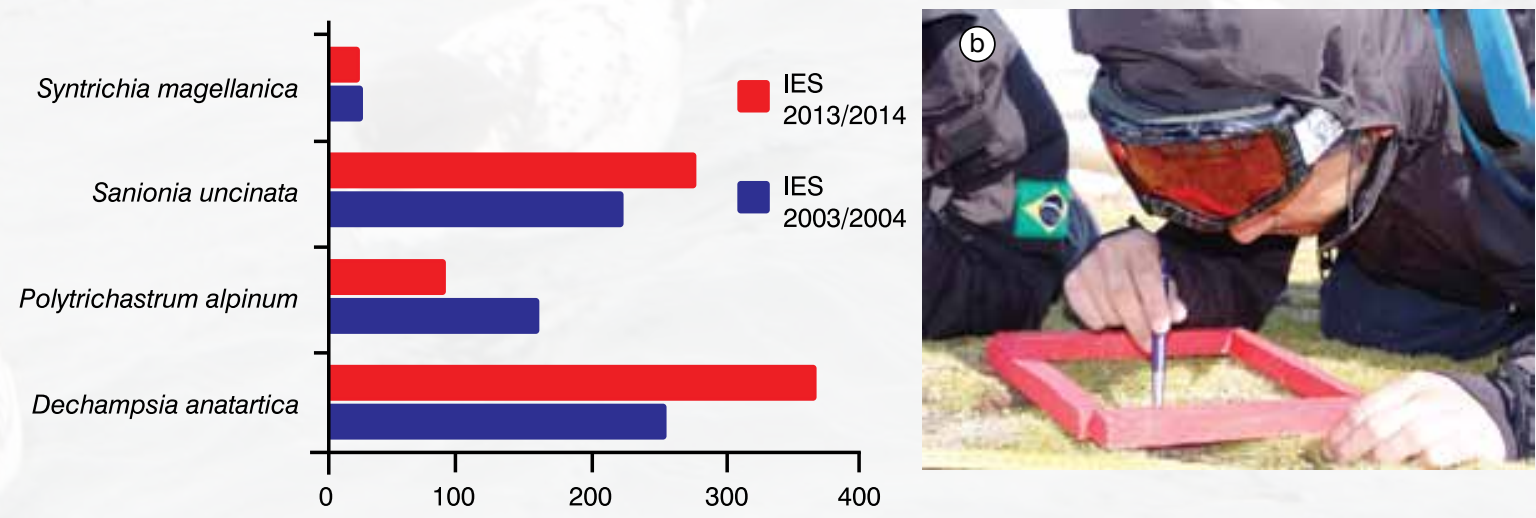

Figure 1. a: Comparative data from the IES, austral summer 2003/2004 According to Victoria et al. (2009). And current study austral summer 2013/2014 Figure1: b: Braun-Blanquet phytosociology methods, adapted to Antarctic conditions. 
alpinum and Dechampsia Antartica. Both species shows two- fold increases of IES values in ten 10 years.

\section{Discussion}

From the data obtained in this study, we observed considerable changes in floristic composition of plant species. We know that the Polish Antarctic Station was one of the most impacted areas in the Admiralty Bay, mainly by human actions (Olech, 1996) this is possibly one of the factors that may be causing these changes. The ecological succession in Antarctica is another factor that may be occurring, since over the years the temperature in the area is increasing. The Dechampsia antarctica has been the most dominant species in this area, being represented in all plant communities sampled, being found in 250 of the 332 quadrats sampled, according of early studies (Victoria et al., 2009) this species show lower ratios IES $=245.8$. However further studies and analyzes in other areas of Maritime Antarctica should be conducted to monitor and track any responses that these plant communities are showing.

\section{Conclusion}

This quantitative phytosociological study demonstrates how this method can be efficient to describe the plant communities in Antarctica. It also demonstrated how the phanerogamic flora should be better studied on the continent. A descriptive and quantitative database can collaborate for continuous monitoring of plant communities in Antarctica, contributing to the conservation of plant species in the area.

\section{Acknowledgements}

This work was supported by the Brazilian Antarctic Program through the National Council for Research and Development - CNPq (process no. 574018/2008), Research Foundation of the State of Rio de Janeiro - FAPERJ (process E-26/170.023/2008), Ministry of Environment MMA, Ministry of Science and Technology - MCT and Interministerial Commission for Sea Resources - CIRM, where the authors appreciate the financial support and logistic needed to undertake this work.

\section{References}

Braun-Blanquet, J. 1932. Plant sociology: the study of plant communities. New York: McGraw-Hill.

Kanda, H. (1986). Moss communities in some ice-free areas along the Söya Coast, East Antarctica [Special Issue]. Memoirs of Natural Institute of Polar Research, 44, 229-240.

Lara, F., \& Mazimpaka, V. (1998). Sucession of epiphytic bryophytes in Quercus pyrenaica forest from Spanish Central Range (Iberian Peninsula). Nova Hedwigia, 67, 125-138.

Lewis-Smith, R. I. 2001. Plant colonisation response to climate change in the Antarctic. Folia facultatis Scientiarum Naturalium Universitatis Purkynianae Brunensis, Geográfica, 25, 19-33.

Olech, M. (1996). Human impact on terrestrial ecosystems in west Antarctica. Proceedings of the NIPR Symposium on Polar Biology, 9, 299-306.

Pereira, A. B., \& Putzke, J. (1994). Floristic composition of Stinker Point, Elephant Island, Antarc. Korean Journal of Polar Research, 5(2), 37-47.

Victoria, F. C., \& Pereira, A. B. (2007). Índice de valor ecológico (IES) como ferramenta para estudos fitossociológicos e conservação das espécies de musgos na Baía do Almirantado, Ilha Rei George, Antártica Marítima. Oecologia Brasiliensis, 11(1), 50-55. http://dx.doi.org/10.4257/oeco.2007.1101.06

Victoria, F. C., Pereira, A. B., \& Pinheiro-da-Costa, D. (2009). Composition and distribution of moss formations in the ice-free areas adjoining the Arctowski region, Admiralty Bay, King George Island, Antarctica. Iheringia, Série Botânica, 64(1), 81-91. 